місце в навчальному процесі, носити системний характер і охоплювати всі етапи навчання. На уроках мови наохдіно використовувати завдання для перевірки засвоєння учнями початкових класів змісту лінгвоукраїнознавчої змістової лінії згідно 3 програмовим матеріалом, оволодіння теоретичними положеннями, орфографічними правилами, граматичними засобами, що спонукають учнів до вмінь розпізнавати правильне i помилкове у слововживанні, аналізувати, класифікувати, зіставляти і трансформувати ці вміння в навички.

\title{
Література
}

1. Богуш А. М. Мовленнєва готовність старших дошкільників до навчання у школі / А. М. Богуш, Н. Є. Шиліна. - Одеса : ПНЦ АПН України, 2003. - 335 с.

2. Державний стандарт початкової загальної освіти // Інформ. зб. Мін-ва освіти і науки України. - 2006. - № 2-3. - С. 3-50.

3. Концепція навчання державної мови в Україні / О. Біляєв, Л. Скуратівський, Л. Симоненкова, Г. Шелехова // Дивослово. - 1996. - № 1. - С. 16-22.

Стаття надійшла до редакції 18.05.2012 р.

УДК 378.147

Т. В. Мандрико, викладач-методист,

Н. В. Михайленко, магістр педагогіки вищої школи, Вищий комунальний навчальний заклад Сумської обласної ради «Лебединське педагогічне училище імені А.С.Макаренка»

\section{РОЛЬ І МІСЦЕ ІКТ У ВИКЛАДАННІ ПСИХОЛОГО-ПЕДАГОГІЧНИХ ДИСЦИПЛІН} дисииплін.

Мандрико Т. В., Михайленко Н. В. Роль і місие ІКТ у викладанні психолого-педагогічних

У статті з'ясовано, які інформаційні технології $i$ на яких етапах навчання використовуютьсяу навчально-виховному прочесі у ВНЗ І-II рівнів акредитачії, щзо сприяє доступу до якісної освіти для всіх студентів.

Ключові слова: молодший спеціаліст, інновачія, педагогічна технологія, IКT.

Мандрыко Т. В., Михайленко Н. В. Роль и место ИКТ в преподавании психологопедагогических дисииплин.

В статье осветлено, какие информационные технологии и на каких этапах обучения используют в учебно-воспитательном прочессе в вузе I-II уровней аккредитации, что обеспечивает доступ к качественному образованию для всех студентов.

Ключевые слова: младший специалист, инновация, педагогическая технология, ИКТ.

Mandryka T., Mikhailenko N. The role and place of ICT in the teaching of psycho-pedagogical disciplines.

It is rotined in the article, what information technologies and on what stages of teaching use in a teaching-edukated process in Higher Educational Establishments I-II levels of accreditation. In fact for today without the use of ICT it is impossible to provide equal access to high-quality education for all students.

Key words: junior specialist, innovation, pedagogical technology, ICT. 
Постановка проблеми. Сучасна початкова школа характеризується системними змінами у структурі та змісті навчального процесу, що зумовлює необхідність підготовки вчителя нової формації як компетентного професіонала, здатного до формування, розширення досвіду дитини. На державному рівні проблеми підготовки вчителів відображено в законах України «Про освіту», «Про вищу освіту», Державній національній програмі «Освіта» (Україна XXI століття), Національній доктрині розвитку освіти, Державній програмі «Вчитель» тощо. Проте доцільно мати на увазі те, що в навчально-виховній системі традиційного вищого навчального закладу I-II рівнів акредитації наявні певні суперечності: 1) між орієнтацією на систему знань як основу підготовки та особистісним розвитком майбутнього фахівця; 2) між традиційним підходом до оцінки якості підготовки спеціаліста та сучасним ринком освітніх послуг; 3) між потребами у впровадженні ефективних педагогічних технологій і недостатнім науково-методичним забезпеченням розробки й поширення сучасних педагогічних технологій; 4) між вимогами ринку праці та готовністю вищої школи до підготовки конкурентоспроможного спеціаліста-випускника. Це є підставою для того, щоб розробляти та впроваджувати у навчально-виховний процес ВНЗ I-II рівнів акредитації інноваційні педагогічні технології.

Аналіз публікацій і досліджень. Сучасна психолого-педагогічна наука створила значну систему теоретико-практичних знань із питання організації навчально-вихованого процесу в навчальних закладах I-II рівнів акредитації. Проблеми педагогічної інноватики розглядали Л. Даниленко, О. Киричук, М. Поташник, В. Паламарчук та інші. Питання розроблення та впровадження освітніх технологій, педагогічних технологій навчання і виховання загалом розглядали В. Боголюбов, І. Зязюн, А. Насімчук, Г. Селевко та інші. Безпосередньо технології навчання у вищих навальних закладах різного рівня вивчали В. Безпалько, В. Бондар, В. Свдокимов, М. Кларін, І. Прокопенко та інші.

Аналіз позицій сучасних дослідників засвідчує розмаїття підходів до сутнісної характеристики педагогічної технології, яка розглядається як системний метод (С. Гончаренко, І. Прокопенко, В. Свдокимов), дидактична система (О. Савченко), діяльність (В. Сластьонін), конструювання, проектування навчального процесу (І. Богданова, В. Паламарчук), структуроване проектування (В. Безпалько, І. Підласий) та інші.

Найбільш вагому частину в цих технологіях мають інформаційні технології навчання. Основний напрямок використання нових інформаційних технологій навчання грунтуються на можливостях сучасної комп'ютерної техніки. Нині розроблено багато різних методик упровадження комп'ютерів у навчальний процес, деякі з них практично використовуються в поєднанні із своїми програмними продуктами. Однак виникає багато запитань щодо впливу цих методик на те, як реагують студенти на такі форми навчання, як вони засвоюють матеріал при дотриманні цих технологій, на яких етапах уроку можна застосовувати комп'ютер у навчанні, якого віку учні готові до таких форм навчання, як впливає ця технологія на фізіологічні та психологічні 
вікові особливості студентів. Проблема комп'ютеризації освіти стосується не тільки студентів - як суб'єкта навчання, а й викладачів - як вони володіють новими методиками. Мова йде про зміну змісту освіти, про оволодіння інформаційною культурою, під якою розуміємо один із складників загальної культури, що по суті є вищим виявом освіченості, зокрема й особистих якостей людини, іiі професійної компетентності. Сучасна позиція провідних психологів і педагогів (О. Тихомиров, Е. Машбиц, В. Рубцов, Б. Гершунський та інші) полягає в тому, що ІКТ розглядаються не тільки як засіб обробки інформації, але і як засіб впливу на психіку людини. Комп'ютеризація в загальному соціальному розумінні має зробити працю викладача більш продуктивною, підвищити іiі творчий зміст, сприяти всебічному розвитку особистості $[1 ; 3 ; 6 ; 7]$.

Мета статті. Розкрити роль і місце ІКТ у викладанні психологопедагогічних дисциплін у ВНЗ І-ІІ рівня акредитації.

Виклад основного матеріалу. Запровадження в навчально-виховний процес ВНЗ I-II рівня акредитації IКТ $\epsilon$ вимогою часу. Із початком комп'ютеризації навчальних закладів у школу має прийти вчитель, незалежно від рівня, типу, форми власності закладу та рівня своєї кваліфікації має вміти орієнтуватися в інформаційному просторі, отримувати інформацію та оперувати нею відповідно до власних потреб і вимог сучасного високотехнологічного суспільства, а саме:

- створювати: текстові документи; таблиці; малюнки; діаграми; презентації;

- використовувати: Інтернет-технології; локальні мережі; бази даних;

- здійснювати: анкетування; діагностування; тестування; пошук необхідної інформації в мережі інтернет.

Як показує сучасна педагогічна практика, НITH спрямовані на розв'язання переважно таких чотирьох типів дидактичних завдань:

- комп'ютер використовується як допоміжний засіб для більш ефективного розв'язання системи дидактичних завдань, що вже існує (при цьому, змістом об'єкта засвоєння в комп'ютерній навчальній програмі такого типу є довідкова інформація, інструкції, обчислювальні операції, демонстрація та інше;

- комп'ютер може бути засобом, на який покладено розв'язання окремих дидактичних завдань при збереженні загальної структури, цілей і завдань безмашинного навчання (при цьому сам навчальний зміст не закладається в комп’ютер, він виконує функції контролера, тренажера тощо. Ця функція широко представлена в розгалужених діалогових системах, що моделюють діяльність учителя. Нині найчастіше використовуються довідково-контролюючі програми);

- використання комп'ютера дозволяє визначати й розв'язувати нові дидактичні завдання, що не можна здійснити традиційним шляхом (характерними є імітаційно-моделюючі програми);

- комп'ютер може бути використаний як засіб, що моделює зміст об'єктів засвоєння шляхом його конструювання (при цьому реалізуються принципово нові стратегії навчання; прикладом цього напрямку розробок $\epsilon$ так звані «комп'ютерні навчальні оточення» чи «мікросвіти», що становлять моделі галузей знань, які засвоюються) [2, с. 10-12]. 
Мультимедійні засоби навчання є універсальними, так як можуть бути використані на різних етапах навчання:

- у поясненні нового матеріалу як ілюстрації; мотивації;

- як постановка проблеми перед вивченням нового матеріалу під час

- для контролю знань та під час закріплення і узагальнення.

Мультимедійні засоби навчання допомагають викладачу:

- активізувати навчальну роботу студентів і посилити мотивацію навчання;

- забезпечити швидкий зворотній зв'язок i широкі можливості діалогізації навчального процесу;

- розширити поле самостійної діяльності студентів;

- створити навчальні середовища, які забезпечують «занурення» студента в уявний світ, у певні соціальні та виробничі ситуації.

Для одержання високого навчального ефекту необхідне систематичне використання комп'ютера на будь-якій стадії вивчення матеріалу.

Використовуючи мультимедійний проектор, можна також реалізувати такі види освітньої діяльності:

- демонстрація презентацій занять, створених викладачем, презентацій студентів тощо;

- робота з текстом, зображенням, відеоматеріалами;

- робота з будь-якими програмами Microsoft: Word, Excel, PowerPoint тощо.

До сучасних інформаційних технологій, які використовують у навчальному процесі, належать електронні бібліотеки, посібники, довідковопошукові системи Internet. Найбільш ефективними засобами серед різноманіття навчальних мультимедійних технологій $є$ :

- автоматизовані навчальні системи;

- мультимедійні презентації;

- комп'ютерні тренажери;

- відеодемонстрації;

- навчальні фільми.

Одним із цікавих прийомів використання на заняттях психологопедагогічних дисциплін $є$ фотомонтаж, що становить відхід від звичайної презентації i спробу пошуку власного відкриття, нового пізнання та осмислення. Це дозволяє, наприклад, використати матеріали нашого музею спадщини А. Макаренка. Етапи такої роботи:

- Відвідування музею.

- Вибір фото, що були б ключовими у відображенні сутності особистості.

- Визначення напрямку дослідження: відкриття через творчість; відкриття через один ключовий образ; відкриття через справу; відкриття через захоплення; відкриття через сучасні розвідки.

- Поділ дослідження на тематичні блоки.

- Формулювання проблемного запитання чи гіпотези.

- Поглиблення ілюстрацій змістом.

- Поєднання слайдів розкриває одну ідею, якою необхідно захопити учнів. 
- Корекція структури дослідження, виокремлення головного та відкидання несуттєвого, гармонізація змісту та форми.

Фотомонтаж - це не глибоке дослідження, а лише розвідка про окрему грань особистості видатного педагога, цей прийом робить заняття методично змістовним, творчим, оскільки навчає майбутніх учителів спостерігати, визначати найсуттєвіше, сприяє формуванню інтересу до процесу становлення особистості, виробленню навичок висловлення власних думок, їх аргументації.

Як відомо, в останній час великий інтерес науковців викликає такий новий напрямок комп'ютерного навчання, як мережеве навчання. До нього віднесено як роботу в системі Інтернет, WorldWideWeb (WWW), так i використання електронної пошти. У третьому тисячолітті Інтернет стає ефективним засобом навчання. Однією з причин цього є те, що він дозволяє контактувати з великою кількістю людей, чиї інтереси збігаються, і відтак надається реальна можливість обміну думками, проведення дискусій, розширення світогляду й знань. Завдяки спілкуванню формуються позитивні особистісні якості, вміння творчо мислити, виховується культура спілкування зокрема, та загальна культура загалом.

Цифрові бібліотеки, якими користувалися студенти завдяки системі Інтернет, пропонують унікальний безмежний ресурс отримання інформації 3 будь-якого питання. Можна припустити, що вони є більш привабливими для студентів завдяки таким своїм особливостям:

- інформація актуальна (студенти можуть отримати найсучаснішу інформацію стосовно питань, які вони досліджують);

- інформація 3 первинних ресурсів (у багатьох випадках студенти користуються тими ж даними й інформаційними джерелами, що і науковці);

- інформація різнобічна (забезпечує широту й глибину у багатьох підпорядкованих галузях; у звичайних бібліотеках набір матеріалу з потрібного предмета обмежений; цифрові бібліотеки можуть розширювати діапазон необмежено, надаючи доступ до безпрецедентної широти інформаційних джерел);

- ресурси представлені в різних форматах (зокрема, інформація доступна в цифровій формі для легкої маніпуляції й використання);

- інформація доступна в будь-який час.

Так, під час підготовки до занять з психолого-педагогічних дисциплін студенти можуть отримати завдання, працюючи в системі Інтернет, підготувати матеріал із запропонованих питань. Важливою особливістю системи Інтернет як засобу навчання є й те, що завдяки їй стають доступними світові ресурси освіти. У мережі можна знайти будь-яку інформацію, яка цікавить. Тому ця робота є також частиною підготовки до самоосвіти.

Висновки. Інноваційною основою підготовки молодших спеціалістів у BH3 I-II рівня акредитації є створення такого освітнього середовища, яке має врахувати ціннісні орієнтації та мотиваційну сферу студентів, їхню професійну позицію і спрямованість. Подальшого вивчення потребує питання впровадження IКТ у процес вивчення психолого-педагогічних дисциплін як базових у професійній підготовці спеціалістів початкової ланки освіти. 


\section{Література}

1. Андрущенко В. П. Роздуми про освіту: статті, нариси, інтерв'ю / В. П. Андрущенко. - К. : Знання України, 2004. - 804 с.

2. Вовковінська Н. В. Як створити комп’ютерну презентацію / Н.В. Вовковінська. - К. : Шкільний світ, 2009. - 128 с.

3. Гершунский Б. С. Компьютеризиция в сфере образования: проблемы и перспективы / Б. С. Гершунский. - М., 1987. - 264 с.

4. Савченко О. Удосконалення професійної підготовки майбутніх вчителів початкових класів / Олександра Савченко // Початкова школа. - 2001. - №7. - С. 1-4.

5. Сиротенко К. Інформаційні технології - чинник формування Школи майбутнього / К.Сиротенко // Директор школи. - 2010. - №6. - С. 5-8.

6. Селевко Г.К. Современные образовательные технологии : [учебн. пособ.] / Г.К. Селевко. - М., 1998. - 256 с.

7. Слєпкань 3. I. Наукові засади педагогічного процесу у вищій школі: [навч. посіб.] / 3. І. Слєпкань. - К.: Вища школа, 2005. - 239 с.

Стаття надійшла до редакції 19.05.2012 р.

УДК [377.36.011.3-051

О. А. Одинець, acniрант, Луганський національний університет імені Тараса Шевченка

\section{ПРОФЕСІЙНА ПІДГОТОВКА КОМПЕТЕНТНОГО ФАХІВЦЯ З ПЕРУКАРСЬКОГО МИСТЕЦТВА ТА ДЕКОРАТИВНОЇ КОСМЕТИКИ ЗАСОБАМИ МИСТЕЦТВА}

Одинець О.А. Професійна підготовка компетентного фахівия з перукарського мистеитва та декоративної косметики засобами мистецтва.

У статті розглядається поняття «професійна підготовка» та ії структура, аналізуються різні підходи до визначення сутності поняття «компетентність», «засоби мистецтвва».

Ключові слова: професійна підготовка, компетентність, засоби мистецтва.

Одинец Е.А.Профессиональная подготовка компетентного специалиста по парикмахерскому искусству и декоративной косметике средствами искусства.

В статье рассматривается понятие «профессиональная подготовка» и ее структура, анализируются разные подходы к понятию «компетентность специалиста».

Ключевые слова: профессиональная подготовка, компетентность, средства искусства.

Odinets E. The training of a competent professional in hairdressing and make-art methods.

This article discusses the concept of «training» and its structure are analyzed different approaches to the concept of «competence of a specialist».

Key words: training, competence, complex art.

У Законі України «Про освіту» зазначено: «Метою освіти є всебічний розвиток людини як особистості та найвищої цінності суспільства, розвиток іiі талантів, розумових і фізичних здібностей, виховання високих моральних якостей, формування громадян, здатних до свідомого суспільного вибору, збагачення на цій основі інтелектуального, творчого, культурного потенціалу народу, забезпечення народного господарства кваліфікованими фахівцями» [4, с. 6].

Однією з актуальних проблем нині варто назвати модернізацію системи підготовки у ВНЗ I-II рівня акредитації, яка допоки не відповідає оновленим 